\title{
Competitive Relationships and Yield Advantage of Intercropping Faba Bean with Sugar Beet under Bio-Organic Additives and Mineral Nitrogen Fertilizer Rates
}

\author{
Y. E. El-Ghobashi ${ }^{1}$, A. E. M. Eata ${ }^{2}$ \\ ${ }^{1}$ Crop Intensification Research Department, Field Crops Research Institute, Agricultural Research Center, Giza, Egypt \\ ${ }^{2}$ Department of Vegetable Research, Horticulture Research Institute, Agricultural Research Center, Giza, Egypt \\ Email: dryasser809@gmail.com
}

How to cite this paper: El-Ghobashi, Y.E. and Eata, A.E.M. (2020) Competitive Relationships and Yield Advantage of Intercropping Faba Bean with Sugar Beet under Bio-Organic Additives and Mineral Nitrogen Fertilizer Rates. Agricultural Sciences, 11, 369-389.

https://doi.org/10.4236/as.2020.114022

Received: February 24, 2020

Accepted: March 29, 2020

Published: April 1, 2020

Copyright $\odot 2020$ by author(s) and Scientific Research Publishing Inc. This work is licensed under the Creative Commons Attribution International License (CC BY 4.0).

http://creativecommons.org/licenses/by/4.0/

\begin{abstract}
A field experiment was conducted at El-Serw Agricultural Research Station, Damietta Governorate, Egypt during 2016/2017 and 2017/2018 seasons to reduce mineral $\mathrm{N}$ inputs of sugar beet with increased land use efficiency and profitability under intercropping conditions. Seven treatments included five treatments (90 kg nitrogen " $\mathrm{N}$ " $+30 \mathrm{~m}^{3}$ farm yard manure "FYM"/fad, $80 \mathrm{~kg}$ $\mathrm{N}+30 \mathrm{~m}^{3} \mathrm{FYM} / \mathrm{fad}, 70 \mathrm{~kg} \mathrm{~N}+30 \mathrm{~m}^{3} \mathrm{FYM} /$ fad and $400 \mathrm{~g}$ of Cerealine $+30 \mathrm{~m}^{3}$ $\mathrm{FYM} /$ fad for intercropping faba bean cultivar Spanish with sugar beet cultivar Gloria) and two treatments ( 90 and $20 \mathrm{~kg} \mathrm{~N} /$ fad for solid culture of sugar beet and faba bean, respectively, as recommended mineral $\mathrm{N}$ fertilizer rate) were compared in a randomized complete block design with three replications. Solid culture of sugar beet with the application of recommended rate $(90 \mathrm{~kg}$ $\mathrm{N} / \mathrm{fad}$ ) gave the highest top, root and sugar yields/fad, as well as the percentage of purity compared with the other treatments in both seasons. Intercropping faba bean with sugar beet plants with application of $90 \mathrm{~kg} \mathrm{~N}+30 \mathrm{~m}^{3}$ FYM/fad gave the highest number of leaves/plant, leaf area/plant, root length, root diameter and root weight/plant followed by intercropped sugar beet plants that fertilized with $80 \mathrm{~kg} \mathrm{~N}+30 \mathrm{~m}^{3} \mathrm{FYM} /$ fad compared with the other treatments in both seasons. On the other hand, intercropped sugar beet that received $400 \mathrm{~g}$ of Cerealine $+30 \mathrm{~m}^{3} \mathrm{FYM} / \mathrm{fad}$ had the highest percentages of T.S.S. and sucrose followed by $70 \mathrm{~kg} \mathrm{~N}+30 \mathrm{~m}^{3} \mathrm{FYM} /$ fad compared with the other treatments in both seasons. Solid culture of faba bean with the application of $20 \mathrm{~kg} \mathrm{~N} /$ fad gave the highest plant height, number of seeds/pod and seed yield/fad, meanwhile the highest number of branches/plant and pod length were achieved by intercropping faba bean with sugar beet with appli-
\end{abstract}


cation of $90 \mathrm{~kg} \mathrm{~N}+30 \mathrm{~m}^{3} \mathrm{FYM} /$ fad followed by intercropped faba bean plants that fertilized with $80 \mathrm{~kg} \mathrm{~N}+30 \mathrm{~m}^{3} \mathrm{FYM} /$ fad compared with the other treatments in both seasons. However, intercropped faba bean plants that fertilized with $70 \mathrm{~kg} \mathrm{~N}+30 \mathrm{~m}^{3} \mathrm{FYM} /$ fad gave the highest number of pods per plant, number of seeds per pod, seed index and seed yield per plant compared with the other treatments in both seasons. Land equivalent ratio (LER), land equivalent coefficient (LEC) and relative crowding coefficient (RCC) were high by intercropping faba bean with sugar beet with the application of $80 \mathrm{~kg}$ $\mathrm{N}+30 \mathrm{~m}^{3} \mathrm{FYM} /$ fad indicating yield advantage was achieved. The value of aggressivity (Agg) of sugar beet was negative for all combinations indicating that sugar beet is dominated component in the present study. Intercropping faba bean with sugar beet with the application of $80 \mathrm{~kg} \mathrm{~N}+30 \mathrm{~m}^{3} \mathrm{FYM} / \mathrm{fad}$ achieved higher total income and monetary advantage index (MAI) than the other treatments. Growing sugar beet plants in both sides of beds $(1.2 \mathrm{~m}$ width) with one faba bean row in middle of sugar beet beds with the application of $80 \mathrm{~kg} \mathrm{~N}+30 \mathrm{~m}^{3} \mathrm{FYM} /$ fad decreased mineral $\mathrm{N}$ fertilizer rate by $10.00 \%$ of the recommended sugar beet mineral $\mathrm{N}$ fertilizer rate, as well as increased land usage and profitability for Egyptian farmers compared with sugar beet solid culture.

\section{Keywords}

Intercropping, Sugar Beet, Faba Bean, Mineral N Fertilizer, FYM, Cerealine, Competitive Relationships, Intercropping Economic Advantage

\section{Introduction}

Nowadays food problem is one of the most important problems in the world, attributed to the drastically growing numbers of the population, limited cultivated area and declining availability of fresh irrigation water. Thus, the challenge of sustainable agriculture is more serious in developing countries, including Egypt. Population growth always requires an increase in the use of available environmental resources around the world. It is considerable pressure on available environmental resources especially water that is one of the major factors in arid and semiarid regions [1]. The limited water resources in Egypt are the most pressing factors of water issues. However, increased cropping systems to meet world demands will require an increase of $40 \%$ in the area of harvest major crops by 2030 , and that the amount of water allocated to irrigation must increase correspondingly by $14 \%$ [2]. One of the main problems associated with the Egyptian agricultural system is the low size of cultivated land per farmer. On average, $42.9 \%$ of the farmers own or work in field one fad $\left(4200 \mathrm{~m}^{2}\right)$ or less [3]. However, the low soil quality, such as the low hydraulic quality, high soil impedance, salt content and organic matter scarcity, limit the soil productivity seriously [4]. Accordingly, the agriculture intensification had become an urgent necessity to 
optimize the utilizing of limited cultivated areas and to maximize the monetary returns of unit area [5].

Sugar beet (Beta vulgaris L.) is one of the most important sugar crops in the world. It is one of the most important crops for sugar production after sugar cane in Egypt. It has the ability to grown on newly reclaimed soils that suffer from salinity, sodic and calcareous soils [6]. Also, faba bean (Vicia faba L.) is a major leguminous crop that grown in Egypt; it is an important source of protein for human and animal consumption and it plays a role in the crop rotation. However, the total production of these crops is still insufficient to cover local consumption. From the above-mentioned facts, there is a great need to minimize the gap between food material production and consumption by improving the productivity of unit area and crop quality especially in the newly reclaimed area and raising unit area productivity simultaneously through intercropping. In this concern, several investigators found that maximum values of land equivalent ratio (LER) that recorded 1.36 and 1.38 were obtained by intercropping faba bean with sugar beet in the first and second seasons, respectively along with the highest values of total income [7] [8] and [9]. Moreover, the relative crowding coefficient (RCC) in intercropping faba bean with sugar beet exceeded the unit indicating that yield advantage of both components was higher than expected, faba bean was the dominant crops and sugar beet was the dominated [10].

According to Sharma and Mittra [11], the use of inorganic fertilizers alone has not been helpful under intensive agriculture because it aggravates soil degradation. It has been found that increasing mineral $\mathrm{N}$ fertilization rate up to 92 $\mathrm{kg} /$ fad had significantly increased root fresh weight, root, and sugar yield but decreased sucrose percentage [12]. Consequently, attention is focused on using various forms of organo-mineral fertilizer composts as partial substitutions to mineral fertilizers. Such practices should be investigated under normal or saline conditions in arid and semi-arid regions as sources of nutrients. Organic manure, such as farmyard manure (FYM), green manure, organic amendment and municipal solid waste, has been used as a source of plant nutrients and organic matter to improve fertility conditions of agricultural lands for a long time [13]. Particularly, Celik et al. [14] showed that the addition of organic materials of various origins to soil has been one of the most common practices to improve soil physical properties. Thus, FYM is a vital organic resource and their extensively used in soil management for sustainable agriculture [15].

Recently, some investigators tried to utilize the FYM and bio fertilization to decrease the cost and minimize the pollution compared to mineral fertilizers and drainage water, where Zalat and Nemeat Alla [16] reported that manure could be an available source of nutrients for sugar beet. Also, Javaheri et al. [17] found that FYM surpassed the check treatment (without FYM) for sugar beet traits (root diameter, root length, fresh weight of root, and root, top and sugar yield per fad), whereas percentages of the total soluble solids and sucrose were tended to decrease with the addition of FYM with 20 tons/fad [7]. The application of 
manure (30 tons/ha) before planting sugar beet crop, resulted in a $17 \%$ increase in sugar yield [18]. However, Maid and Fischbeck [19] studied the effects of long-term organic manuring and additional doses of mineral $\mathrm{N}$-fertilizer $(0,80$, 160 , and $240 \mathrm{~kg} \mathrm{~N} / \mathrm{ha}$ ) on growth and quality of sugar beet. They found that sugar beet without manure treatment always developed higher sugar content and lower concentrations of alpha-amino-N, sodium and, potassium (K) compared with beet from plots with manure application. Moreover, application of FYM with a rate of 20 tons/fad significantly increased shoot, root and sugar yields/fad of sugar beet [20].

Obviously, there were under-ground interactions and rhizosphere effects between intercropped crops, which have an important role in the advantage effect of intercropping [21]. On the other hand, Abdel-Wahab and Said [22] showed that the highest plant dry matter, total $\mathrm{N}$-content and yield of broad bean were achieved when compost was combined with Serratia and applied to the soil. Organic manure gave superiority in total pods yield and its components of the broad bean as mentioned by Mahmoud et al. [23]. In another study, Mohamed and Gomaa [24] indicated that the biofertilization of faba bean with the combined inoculum of Rhizobium and Candida when accompanied with either $5 \mathrm{~m}^{3}$ or $10 \mathrm{~m}^{3}$ of FYM increased each of pods number/plant, seeds number/pod and pod weight. Certainly, microbes have a high ability to convert or mineralize organic $\mathrm{N}$ fertilizers to nitrate and ammonium [25]. The application of $100 \mathrm{~kg}$ mineral $\mathrm{N} /$ fad to sugar beet produced the highest growth trait followed by $80 \mathrm{~kg}$ $\mathrm{N} /$ fad along with bio fertilization [26]. They added that the highest root and top yields obtained from adding $100 \mathrm{~kg} \mathrm{~N} / \mathrm{fad}$, while sugar yield was highest with the combination of bio fertilization (Azotobacter or Azosperlum) along 60 or $80 \mathrm{~kg}$ $\mathrm{N} /$ fad followed by $100 \mathrm{~kg} \mathrm{~N} /$ fad. Consequently, application of 90 or $72 \mathrm{~kg}$ mineral $\mathrm{N}$ in combination with biofertilizers (Cerealine or Rizobacterien) in intercropping faba ben with sugar beet recorded the highest LER and net income compared with the other treatments [27]. The objective of this research was to reduce mineral $\mathrm{N}$ inputs of sugar beet with increased land use efficiency and profitability under intercropping conditions.

\section{Materials and Methods}

A-two year study was carried out at EL-Serw Agricultural Experiments and Research Station (Lat. 31 $24^{\prime} 59^{\prime \prime N}$, Long. $31^{\circ} 48^{\prime} 47^{\prime \prime E}, 16 \mathrm{~m}$ a.s.l.), Agricultural Research Center (ARC), Damietta governorate, Egypt during two successive seasons; 2016/2017 and 2017/2018 to reduce mineral $\mathrm{N}$ inputs of sugar beet with increased land use efficiency and profitability under intercropping conditions. This study included seven treatments as follows: $\mathrm{T}_{1}$ : Intercropping faba bean with sugar beet with application of $90 \mathrm{~kg} \mathrm{~N} /$ fad. $\mathrm{T}_{2}$ : Intercropping faba bean with sugar beet with application of $90 \mathrm{~kg} \mathrm{~N}+30 \mathrm{~m}^{3} \mathrm{FYM} / \mathrm{fad} . \mathrm{T}_{3}$ : Intercropping faba bean with sugar beet with application of $80 \mathrm{~kg} \mathrm{~N}+30 \mathrm{~m}^{3} \mathrm{FYM} /$ fad. $\mathrm{T}_{4}$ : Intercropping faba bean with sugar beet with application of $70 \mathrm{~kg} \mathrm{~N}+30 \mathrm{~m}^{3} \mathrm{FYM}$ 
/fad. $\mathrm{T}_{5}$ : Intercropping faba bean with sugar beet with application of $400 \mathrm{~g}$ of Cerealine $+30 \mathrm{~m}^{3} \mathrm{FYM} /$ fad. $\mathrm{T}_{6}$ : Solid culture of sugar beet with application of the recommended $\mathrm{N}$ fertilizer rate $\left(90 \mathrm{~kg} \mathrm{~N} /\right.$ fad). $\mathrm{T}_{7}$ : Solid culture of faba bean with application of the recommended $\mathrm{N}$ fertilizer rate $(20 \mathrm{~kg} \mathrm{~N} / \mathrm{fad})$. Sugar beet cultivar "Gloria" and faba bean (Vicia faba L. var. major) cultivar "Spanish" were used in this study. Rice crop was the preceding crop and the furrow irrigation was the irrigation system in the region. Physical and chemical properties of the soil (0 - $20 \mathrm{~cm}$ depth) were analyzed by Chemistry and Soils Laboratory, EL-Serw Agricultural Experiments and Research Station, ARC (Table 1) according to Chapman and Pratt [28]. Calcium super phosphate $\left(15.5 \% \mathrm{P}_{2} \mathrm{O}_{5}\right)$ was applied at rate of $200 \mathrm{~kg} /$ fad during soil preparation in the two winter seasons. Mineral $\mathrm{N}$ fertilizer was applied in form of urea $(46 \% \mathrm{~N})$ in two equal doses; the first dose was applied after thinning ( 35 days after sowing) and the second one was applied before the third irrigation (70 days after sowing) according to every treatment.

Fifty $\mathrm{kg} /$ fad from $\mathrm{K}$ sulfate $\left(48.0 \% \mathrm{~K}_{2} \mathrm{O}\right)$ was applied in two equal doses; the first dose was applied during soil perpetration and the second one was applied with the second dose of $\mathrm{N}$ fertilization. Cerialine (Azospirillum brzsilense and Bacillus polymyxa) as commercial products were produced by Bio fertilizer Unit, Agriculture Research Center (ARC), Giza, Egypt, which included free-living bacteria able to fix atmospheric $\mathrm{N}$ in the rhizosphere of soil. FYM that included 30 $\mathrm{m}^{3} / \mathrm{fad}$ was incorporated into the soil before sowing according to each treatment. FYM was analyzed by Chemistry and Soils Laboratory, EL-Serw Agricultural Experiments and Research Station, ARC (Table 2).

Table 1. Physical and chemical properties of the soil in the experimental site in two growing seasons (2016/2017 and 2017/2018).

\begin{tabular}{ccc}
\hline Soil properties (0 - 20 cm depth) & \multicolumn{2}{c}{ Growing season } \\
\hline Physical analysis & $2016 / 2017$ & $2017 / 2018$ \\
Coarse sand (\%) & 1.99 & 1.88 \\
Fine sand (\%) & 8.85 & 9.32 \\
Silt (\%) & 22.36 & 22.50 \\
Clay (\%) & 66.90 & 66.55 \\
Texture class & Clay \\
Chemical analysis & & 7.50 \\
pH & 7.25 & 0.94 \\
Organic matter, \% & 0.91 & 9.47 \\
Available phosphorus “P” (ppm) & 9.32 & 198.12 \\
Available potassium “K” (ppm) & 194.23 & 44.52 \\
Available N (ppm) & 42.34 & 4.37 \\
\hline Electrical conductivity (E.C.ds/m $\left.{ }^{2}\right)$ & 4.92 & 8.87 \\
\hline
\end{tabular}


Table 2. Analysis of FYM in the two growing seasons (2016/2017 and 2017/2018).

\begin{tabular}{ccc}
\hline \multirow{2}{*}{ Properties } & \multicolumn{2}{c}{ Growing season } \\
\cline { 2 - 3 } & $\mathbf{2 0 1 6 / 2 0 1 7}$ & $\mathbf{2 0 1 7 / 2 0 1 8}$ \\
\hline $\mathrm{pH}$ & 8.04 & 7.51 \\
Electrical conductivity (E.C. ds $\left./ \mathrm{m}^{2}\right)$ & 3.27 & 3.12 \\
Organic matter (\%) & 10.63 & 10.40 \\
$\mathrm{C} / \mathrm{N}$ ratio (\%) & 12.04 & 11.92 \\
$\mathrm{~N}(\mathrm{ppm})$ & 0.01 & 0.02 \\
$\mathrm{P}(\mathrm{ppm})$ & 0.27 & 0.30 \\
$\mathrm{~K}(\mathrm{ppm})$ & 3.96 & 3.74 \\
Moisture (\%) & 30.0 & 30.00 \\
\hline
\end{tabular}

Seeds of sugar beet and faba bean were inoculated with Cerealine at a rate of $400 \mathrm{~g} / \mathrm{fad}$ and Arabic gum was used as a sticking agent at sowing. Sugar beet and faba bean seeds were sown on $1^{\text {st }}$ and $5^{\text {th }}$ October in 2016/2017 and 2017/2018 seasons, respectively. Faba bean and sugar beet yields were harvested on $5^{\text {th }}$ March and $20^{\text {th }}$ April in 2016/2017 and $12^{\text {th }}$ March and $25^{\text {th }}$ April in 2017/2018 seasons, respectively. Sugar beet (main crop) seeds were sown on both sides of the beds (1.2 m width) with leaving one plant/hill distanced at $20 \mathrm{~cm}(35,000$ plants/fad). Faba bean (intercrop) seeds were planted in two rows in the middle of sugar beet beds with leaving two plants/hill distanced at $25 \mathrm{~cm}(56,000$ plants/fad). Solid culture of sugar beet plants was conducted by growing their seeds on both sides of the beds (1.2 m width) with leaving one plant/hill (35,000 plants/fad). Solid culture of faba bean plants was conducted by growing their seeds in two rows on ridges $(60 \mathrm{~cm}$ width) with leaving two plants/hill distanced at $20 \mathrm{~cm}(140,000$ plants/fad). The common agricultural practices for growing sugar beet and faba bean were used according to the technical recommendations. A randomized complete block design with three replicates was used. The plot area was $10.8 \mathrm{~m}^{2}$. Each plot consisted of three beds ( $3.0 \mathrm{~m}$ long and $1.2 \mathrm{~m}$ wide) under solid culture of sugar beet and intercropping. Under solid culture of faba bean, each plot consisted of six ridges ( $3.0 \mathrm{~m}$ long and $0.6 \mathrm{~m}$ wide).

\subsection{Data Recorded}

\subsubsection{Sugar Beet Traits}

1) Yield and its attributes:

At harvest date (200 days from sugar beet sowing), ten plants were randomly taken from each plot to estimate the following traits: number of leaves/plant, leaf area/plant $\left(\mathrm{cm}^{2}\right)$, root length $(\mathrm{cm})$, root diameter $(\mathrm{cm})$, root weight/plant $(\mathrm{g})$ and top weight/plant (g). Top and root yields/fad (ton/fad) were recorded on the basis of experimental plot area by harvesting all plants of each plot (one ha $=2.38$ fad), meanwhile sugar yield/fad (ton) was calculated by root yield/fad (ton) $\times$ root sucrose (\%). 
2) Chemical analysis of sugar beet:

Samples of $26 \mathrm{~g}$ fresh root were taken for each treatment to determine:

a) Total soluble solids percentage (TSS \%).

It was estimated by using refractometer set according to A.O.A.C. [29].

Sucrose percentage: It was estimated by using sucrometer set.

b) Purity percentage

It was estimated as method outlined by Carruthers and Oldfield [30] as follows:

$$
\operatorname{Purity}(\%)=\frac{\text { Sucrose }(\%)}{\operatorname{TSS}(\%)} \times 100
$$

\subsubsection{Faba Bean Traits}

At harvest date, ten plants were randomly taken from each plot to estimate the following traits: Plant height $(\mathrm{cm})$, number of branches/plant, pod length $(\mathrm{cm})$, number of pods/plant, number of seeds/pod, 100-seed weight (g), seed yield/plant (g). Seed yield/fad ( $\operatorname{ardab}=155 \mathrm{~kg}$ ) was recorded on the basis of experimental plot area by harvesting all plants of each plot (one ha $=2.38 \mathrm{fad}$ ).

\subsubsection{Competitive Relationships}

1) Land equivalent ratio (LER)

It was calculated as the sum of the fractions of the yields or the intercrops relative to their sole yield according to Andrews and Kassam [31].

$$
\text { LER }=\frac{Y_{a b}}{Y_{a a}}+\frac{Y_{b a}}{Y_{b b}}
$$

where; $Y_{a b}=$ Intercropped crop yield a (sugar beet), $Y_{b a}=$ Intercropped crop yield b (faba bean), $Y_{a a}=$ solid crop a (sugar beet), $Y_{b b}=$ Solid crop b (faba bean).

2) Land equivalent coefficient (LEC)

LEC is a measure of interaction concerned with the strength of relationship [32]. It is calculated as follows: $L E C=L_{a} \times L_{b}$, where: $L_{a}=$ relative yield of crop a (sugar beet) and $L_{b}=$ relative yield of crop b (faba bean).

3) Relative crowding coefficient (RCC)

It was estimated by multiplying the coefficient (RCC) for the first crop $\left(K_{a b}\right)$ by the coefficient of the second crop $\left(K_{b a}\right)$ as according to Banik et al. [33].

$$
K_{a b}=\frac{Y_{a b} \times Z_{b a}}{\left(Y_{a a}-Y_{a b}\right) \times Z_{a b}}, K_{b a}=\frac{Y_{b a} \times Z_{a b}}{\left(Y_{b b}-Y_{b a}\right) \times Z_{b a}}
$$

where; $Z_{a b}=$ the area ratio of the crop (a) when intercropping, $Z_{b a}=$ the area ratio of the crop (b) when intercropping. Then, relative crowding coefficient (RCC) was evaluated as follows:

$$
\mathrm{RCC}=K_{a b} \times K_{b a}
$$

4) Aggressivity (Agg)

It mean a comparison of how much relative yield increase for the intercropped crop (a) on crop (b) with the expected crop to find out which of the two 
crops dominated in yield according to Mc-Gilchrist [34].

For crop (a),

$$
A_{a b}=\frac{Y_{a b}}{Y_{a a} \times Z_{a b}}-\frac{Y_{b a}}{Y_{b b} \times Z_{b a}}
$$

and for crop (b),

$$
A_{b a}=\frac{Y_{b a}}{Y_{b b} \times Z_{b a}}-\frac{Y_{a b}}{Y_{a a} \times Z_{a b}}
$$

\subsubsection{Intercropping Economic Advantage}

1) Total income

It was calculated by determining the total income of intercropping culture as compared to solid culture of sugar beet as follows: Total income of intercropping cultures $=$ Price of sugar beet yield + price of faba bean yield .

2) Monetary advantage index (MAI)

MAI suggests that the economic assessment should be in terms of the value of land saved; this could probably be most assessed on the basis of the rentable value of this land. MAI was calculated according to the formula, suggested by Willey [35]. MAI $=[$ Value of combined intercrops $\times($ LER -1$)] /$ LER. MAI value indicates the profit of the cropping system. The average prices of both cops were 480 L.E. per ton of sugar beet roots and 843 L.E. per ardab of faba bean seeds. One USD = 15 Livre Egyptian (L.E.). These statistics were presented by Bulletin of Statistical Cost Production and Net Return [36].

\subsection{Statistical Analysis}

All data were statistically analyzed according to the technique of analysis of variance (ANOVA) for randomized complete block design by means of "MSTAT-C" software package and least significant difference (LSD) method was used to test the differences between treatment means at $5 \%$ levels of probability, as published by Gomez and Gomez [37].

\section{Results and Discussion}

\subsection{Sugar Beet Traits}

Data in Table 3 show that all the studied traits of sugar beet were significantly influenced by different $\mathrm{N}$ fertilizer combinations in both seasons. Data indicate that intercropped sugar beet plants fertilized with $\mathrm{T}_{2}\left(90 \mathrm{~kg} \mathrm{~N}+30 \mathrm{~m}^{3}\right.$ $\mathrm{FYM} /$ fad) gave the highest number of leaves/plant, leaf area/plant, root length, root diameter and root weight/plant followed by intercropped sugar beet plants that fertilized with $\mathrm{T}_{3}\left(80 \mathrm{~kg} \mathrm{~N}+30 \mathrm{~m}^{3} \mathrm{FYM} / \mathrm{fad}\right)$ compared with the other treatments in both seasons. Meanwhile, the highest top weight/plant (g) was recorded by intercropping faba bean with sugar beet that fertilized with $\mathrm{T}_{3}$ ( $80 \mathrm{~kg} \mathrm{~N}+30 \mathrm{~m}^{3} \mathrm{FYM} / \mathrm{fad}$ ) compared with the other treatments in both seasons. Obviously, an increase in mineral $\mathrm{N}$ fertilizer application can stabilize organic 
Table 3. Response of intercropping faba bean with sugar beet to bio-organic additives and mineral $\mathrm{N}$ fertilizer rates on some sugar beet traits in 2016/2017 and 2017/2018 seasons.

\begin{tabular}{|c|c|c|c|c|c|c|c|c|c|c|c|c|}
\hline \multirow{2}{*}{ Treatment } & \multirow{2}{*}{$\begin{array}{c}\text { No. of } \\
\text { leaves/ } \\
\text { plant }\end{array}$} & \multirow{2}{*}{$\begin{array}{c}\text { Leaf area / } \\
\text { plant } \\
\left(\mathrm{cm}^{2}\right)\end{array}$} & \multirow{2}{*}{$\begin{array}{c}\text { Root } \\
\text { length } \\
(\mathrm{cm})\end{array}$} & \multirow{2}{*}{$\begin{array}{c}\text { Root } \\
\text { diameter } \\
(\mathrm{cm})\end{array}$} & \multirow{2}{*}{$\begin{array}{c}\text { Root } \\
\text { weight/ } \\
\text { plant (g) }\end{array}$} & \multirow{2}{*}{$\begin{array}{c}\text { Top weight/ } \\
\text { plant }(\mathrm{g})\end{array}$} & \multicolumn{3}{|c|}{ Yield (ton/fad) } & \multirow{2}{*}{$\begin{array}{c}\text { T.S.S. } \\
(\%)\end{array}$} & \multirow{2}{*}{$\begin{array}{c}\text { Purity } \\
(\%)\end{array}$} & \multirow{2}{*}{$\begin{array}{c}\text { Sucrose } \\
(\%)\end{array}$} \\
\hline & & & & & & & Top & Root & Sugar & & & \\
\hline \multicolumn{13}{|c|}{$2016 / 2017$ season } \\
\hline $\mathrm{T}_{1}$ & 23.67 & $10,821.67$ & 23.22 & 10.22 & 718.82 & 560.00 & 27.49 & 30.09 & 5.80 & 22.70 & 84.98 & 19.29 \\
\hline $\mathrm{T}_{2}$ & 35.55 & $13,523.33$ & 28.67 & 15.55 & 961.70 & 695.43 & 32.43 & 34.33 & 5.93 & 21.42 & 80.86 & 17.32 \\
\hline $\mathrm{T}_{3}$ & 30.89 & $12,588.33$ & 27.22 & 14.33 & 875.46 & 681.77 & 28.65 & 32.83 & 5.90 & 21.91 & 82.10 & 17.99 \\
\hline $\mathrm{T}_{4}$ & 29.56 & $11,505.67$ & 26.22 & 12.26 & 785.41 & 669.10 & 23.47 & 27.04 & 5.29 & 23.80 & 82.35 & 19.60 \\
\hline $\mathrm{T}_{5}$ & 19.33 & 6165.00 & 19.56 & 7.40 & 601.30 & 484.67 & 18.70 & 20.77 & 4.21 & 24.32 & 83.35 & 20.27 \\
\hline $\mathrm{T}_{6}$ & 27.00 & $12,238.00$ & 24.89 & 12.16 & 792.03 & 634.33 & 30.74 & 37.01 & 7.23 & 22.78 & 85.91 & 19.57 \\
\hline LSD at $5 \%$ & 1.60 & 239.10 & 1.28 & 0.08 & 49.40 & 45.00 & 5.32 & 3.51 & 0.66 & 1.26 & 1.79 & 0.27 \\
\hline \multicolumn{13}{|c|}{$2017 / 2018$ season } \\
\hline $\mathrm{T}_{1}$ & 25.00 & $11,050.00$ & 23.22 & 11.34 & 758.90 & 683.92 & 31.33 & 33.43 & 6.57 & 23.69 & 80.81 & 19.66 \\
\hline $\mathrm{T}_{2}$ & 36.35 & $13,929.33$ & 29.33 & 16.63 & 1092.32 & 800.02 & 33.06 & 35.38 & 6.23 & 22.40 & 80.22 & 17.97 \\
\hline $\mathrm{T}_{3}$ & 33.80 & $12,734.33$ & 28.22 & 15.34 & 1047.88 & 792.22 & 31.47 & 34.21 & 6.37 & 23.20 & 80.39 & 18.65 \\
\hline $\mathrm{T}_{4}$ & 29.67 & $11,635.00$ & 27.21 & 13.29 & 919.00 & 782.43 & 29.97 & 33.01 & 6.65 & 24.98 & 80.70 & 20.16 \\
\hline $\mathrm{T}_{5}$ & 19.67 & 6338.33 & 20.67 & 8.49 & 622.67 & 586.67 & 23.48 & 26.25 & 5.48 & 25.85 & 82.99 & 20.89 \\
\hline $\mathrm{T}_{6}$ & 28.33 & $12,473.33$ & 25.22 & 13.16 & 819.00 & 737.57 & 34.49 & 37.60 & 7.46 & 23.71 & 83.76 & 19.86 \\
\hline LSD at $5 \%$ & 1.87 & 287.14 & 1.08 & 0.11 & 49.18 & 47.86 & 0.79 & 1.63 & 0.28 & 0.21 & 2.72 & 0.56 \\
\hline
\end{tabular}

matter and retard the mineralization of older soil organic matter [38].

It is important to mention that the biological $\mathrm{N}$ fixation by faba bean should be considered, but in this experiment, there was no way to determine the amount of $\mathrm{N}$ derived from fixation and absorption from the soil. Also, the $\mathrm{N}$ percentage in FYM was neglected (Table 2) and not considered in this study because of its small value. These results may be due to FYM that contained an acceptable percentage of organic matter (Table 2) integrated positively with 90 or even $80 \mathrm{~kg} \mathrm{~N} / \mathrm{fad}$ to enhance sugar beet plants for absorbing more soil nutrients than the application of the recommended rate of mineral $\mathrm{N}$ fertilizer only. According to Johnston et al. [39], soil organic matter accumulation improved soil quality through its extensive impacts on soil physical, chemical and biological properties. Generally, changes in soil organic matter strongly influence soil N turnover because of the importance of available carbon for microbial immobilization [40].

However, solid culture of sugar beet with the application of $\mathrm{T}_{1}(90 \mathrm{~kg} \mathrm{~N} / \mathrm{fad}$ ) gave the highest top, root and sugar yields/fad, as well as the percentage of purity compared with the other treatments in both seasons. These results could be attributed to increase in mineral $\mathrm{N}$ fertilizer rate from 70 to $90 \mathrm{~kg} \mathrm{~N} /$ fad increased photosynthetic activities within sugar plants which reflected on greater top, root 
and sugar production per unit area. This was expected as a high $\mathrm{N}$ rate enhanced vegetative growth and consequently the absorption of other nutrients to meet the growth demand.

Accordingly, it is expected that the uptake of soil $\mathrm{N}$ by sugar beet plants increased by increasing the application rate of mineral $\mathrm{N}$ fertilizer from 70 to $90 \mathrm{~kg}$ $\mathrm{N} /$ fad with regardless FYM. The positive effect of $\mathrm{N}$ fertilizer might be due to the increased efficiency of $\mathrm{N}$-fertilization in building up metabolites translocations from leaves to developing roots, thus increased dry matter accumulation [41] as a result of enhancing meristematic activity, stimulation of cell elongation and auxin production [42]. The increase in sugar beet yield/fad of solid culture was related to the increased root yield/fad as reported by Abd-El-Kader [43].

Although $\mathrm{N}$ fixation by legume component in the intercrops was not necessary to increase soil $\mathrm{N}$ stocks with increasing mineral $\mathrm{N}$ fertilizer level from 70 to $90 \mathrm{~kg} \mathrm{~N} / \mathrm{fad}$, intercropping faba bean with sugar beet that fertilized with 70 or 80 $\mathrm{kg} \mathrm{N}+30 \mathrm{~m}^{3} \mathrm{FYM} /$ fad came in the second rank for root and sugar yields/fad after $\mathrm{T}_{6}$ treatment. These results may be due to the variation between the intercrops in their roots changed three dimensions of the rhizosphere of sugar beet roots (from the top to the bottom of the soil profile, from North to South and East to West); and in turn soil N, P, K, and OM stocks were increased. Legume component in the intercrops had an important role in the available soil contents that could increase soil carbon which may contribute to better soil structure [44]. Also, FYM played an important role in enhancing and restoring a range of natural properties of the soil [45]. These results reveal that intercropping faba bean with sugar beet altered the dynamics of organic matter turnover and the rate of nutrient cycling within the soil with decreasing mineral $\mathrm{N}$ fertilizer rate from 90 to $70 \mathrm{~kg} \mathrm{~N} /$ fad. Intercropping faba bean with sugar beet with the application of $\mathrm{T}_{5}$ ( $400 \mathrm{~g}$ of Cerealine $+30 \mathrm{~m}^{3} \mathrm{FYM} / \mathrm{fad}$ ) had the highest percentages of T.S.S. and sucrose followed by $\mathrm{T}_{4}\left(70 \mathrm{~kg} \mathrm{~N}+30 \mathrm{~m}^{3} \mathrm{FYM} / \mathrm{fad}\right)$ compared with the other treatments in both seasons. These results may be due to the Azospirillum brzsilense and Bacillus polymyxa (Cerealine) induced increases in percentages of T.S.S. and sucrose especially at an acceptable percentage of organic matter (Table 2) as result of modification of the structure of soil microbial communities, production of exudates by bacteria and changes in levels of available nutrients. Thus, it is expected that this biological positive effect was enhanced by the high percentage of moisture in FYM (Table 2) that reflected on regulation soil temperature and thereby enhancing chemical and biological activities of the rhizosphere of sugar beet. In this concern, Timmusk and Wagner [46] showed that Paenibacillus polymyxa belongs to the group of plant growth-promoting rhizobacteria. Certainly, bio-fertilizers are extremely benefited in enriching soil fertility with those micro-organisms, which fix atmospheric $\mathrm{N}$ and make plant nutrients more available [47]. N-fixing bacteria play a distinct role in the plant growth through their effect on $\mathrm{N}$-element availability in the rhizosphere in which the plant was grown [48]. 
Obviously, increasing rate of mineral $\mathrm{N}$ fertilizer per fad from 80 to $90 \mathrm{~kg}$ $\mathrm{N} /$ fad was not economically efficient and reduced percentages of T.S.S. and sucrose. Particularly, Afify et al. [49] reported that the inoculation of sugar beet seed with Bacillus megaterium recorded the highest percentage of sucrose for five seasons. Meanwhile, organic manure generally increased the percentage of sucrose [50]. These results are in agreement with those obtained by Ali [51] who showed that the percentage of T.S.S\% was significantly increased when plants inoculated by Bacillus megaterium. Moreover, Omar [52] found that extractable sucrose were slightly increased as FYM increased to 15 and $25 \mathrm{~m}^{3} / \mathrm{fad}$ in two seasons.

\subsection{Faba Bean Traits}

Data in Table 4 indicate that all studied traits of faba bean were significantly affected by different $\mathrm{N}$ fertilizer combinations in both seasons. Data indicate that solid culture of faba bean with the application of $\mathrm{T}_{7}(20 \mathrm{~kg} \mathrm{~N} / \mathrm{fad})$ gave the highest plant height, number of seeds/pod and seed yield/fad compared with the other treatments in both seasons. With regard to plant height, solid culture of faba bean probably formed unfavorable environmental conditions for faba bean growth and development and consequently more amounts of plant hormones compared with intercropped faba bean with sugar beet. So, the observed

Table 4. Response of intercropping faba bean with sugar beet to bio-organic additives and mineral $\mathrm{N}$ fertilizer rates on some faba bean traits in 2016/2017 and 2017/2018 seasons.

\begin{tabular}{|c|c|c|c|c|c|c|c|c|}
\hline Treatment & $\begin{array}{l}\text { Plant height } \\
(\mathrm{cm})\end{array}$ & $\begin{array}{l}\text { No. of branches } \\
\text { /plant }\end{array}$ & $\begin{array}{l}\text { Pod length } \\
\quad(\mathrm{cm})\end{array}$ & $\begin{array}{c}\text { No. of } \\
\text { Pod /plant }\end{array}$ & $\begin{array}{c}\text { No. of seeds } \\
\text { /pod }\end{array}$ & $\begin{array}{l}\text { Seed index } \\
(\mathrm{g})\end{array}$ & $\begin{array}{l}\text { Seed yield/plant } \\
(\mathrm{g})\end{array}$ & $\begin{array}{c}\text { Seed yield } \\
\text { (ardab/fad) }\end{array}$ \\
\hline \multicolumn{9}{|c|}{$2016 / 2017$ seasons } \\
\hline $\mathrm{T}_{1}$ & 66.01 & 5.67 & 13.33 & 8.33 & 4.44 & 85.57 & 70.78 & 6.41 \\
\hline $\mathrm{T}_{2}$ & 94.54 & 7.14 & 15.87 & 9.79 & 3.81 & 89.89 & 92.78 & 6.62 \\
\hline $\mathrm{T}_{3}$ & 83.00 & 6.42 & 15.04 & 11.00 & 4.23 & 115.67 & 108.78 & 7.41 \\
\hline $\mathrm{T}_{4}$ & 71.00 & 6.29 & 14.28 & 12.78 & 5.00 & 126.56 & 127.78 & 8.41 \\
\hline $\mathrm{T}_{5}$ & 61.67 & 4.35 & 12.51 & 7.48 & 3.67 & 80.22 & 79.44 & 4.39 \\
\hline $\mathrm{T}_{7}$ & 109.47 & 5.81 & 14.43 & 10.78 & 4.96 & 86.89 & 87.03 & 14.57 \\
\hline LSD at $5 \%$ & 5.47 & 0.37 & 0.45 & 1.47 & 0.79 & 31.34 & 13.75 & 0.42 \\
\hline \multicolumn{9}{|c|}{$2017 / 2018$ seasons } \\
\hline $\mathrm{T}_{1}$ & 85.23 & 6.11 & 14.57 & 11.56 & 4.33 & 85.22 & 84.22 & 7.07 \\
\hline $\mathrm{T}_{2}$ & 104.64 & 7.46 & 16.67 & 10.78 & 5.78 & 92.00 & 93.89 & 6.70 \\
\hline $\mathrm{T}_{3}$ & 93.34 & 6.22 & 15.68 & 13.00 & 5.22 & 117.67 & 103.89 & 7.77 \\
\hline $\mathrm{T}_{4}$ & 83.55 & 5.43 & 14.65 & 15.78 & 5.33 & 125.53 & 134.22 & 8.66 \\
\hline $\mathrm{T}_{5}$ & 73.10 & 3.90 & 12.11 & 9.67 & 3.66 & 82.22 & 82.78 & 4.81 \\
\hline $\mathrm{T}_{7}$ & 115.74 & 7.11 & 17.40 & 13.78 & 5.22 & 106.22 & 118.89 & 15.79 \\
\hline LSD at $5 \%$ & 5.89 & 0.96 & 0.79 & 1.59 & 0.81 & 3.05 & 9.51 & 0.14 \\
\hline
\end{tabular}


response in plant height of soybean may be primarily attributed to an increase of internode elongation of faba bean plant as a result of increasing plant hormones. With respect to number of seeds/pod, these data may be attributed to intra-specific competition for basic growth resources between the same species (faba bean) was less than inter-specific competition between the two species (faba bean + sugar beet).

On the other hand, it seems that faba bean plant density per unit area played a major role in its productivity per unit area where it reached $40 \%$ of solid culture under intercropping conditions. Similar results were obtained by Mohammed et al. [7], El-Ghobashi [8], Abdel-Galil et al. [9] and El-Shamy et al. [27]. who indicated that faba bean productivity was lower in intercropping than solid plantings. On the other hand, the highest number of branches/plant and pod length were achieved by intercropped faba bean plants that fertilized with $\mathrm{T}_{2}(90 \mathrm{~kg} \mathrm{~N}+$ $30 \mathrm{~m}^{3} \mathrm{FYM} /$ fad) followed by intercropped faba bean plants that fertilized with $\mathrm{T}_{3}$ ( $80 \mathrm{~kg} \mathrm{~N}+30 \mathrm{~m}^{3} \mathrm{FYM} / \mathrm{fad}$ ) compared with the other treatments in both seasons. These results could be due to the application of $90 \mathrm{~kg} \mathrm{~N}+30 \mathrm{~m}^{3} \mathrm{FYM} /$ fad lengthened the vegetative stage and enhanced efficiency of the photosynthetic process of faba bean which reflected on number of branches/plant and pod length. Meanwhile, intercropped faba bean plants that fertilized with $\mathrm{T}_{4}(70 \mathrm{~kg} \mathrm{~N}+30$ $\mathrm{m}^{3} \mathrm{FYM} / \mathrm{fad}$ ) gave the highest number of pods per plant, number of seeds per pod, seed index and seed yield per plant compared with the other treatments in both seasons. It is worthy to note that intercropping faba bean with sugar beet that fertilized with $70 \mathrm{~kg} \mathrm{~N}+30 \mathrm{~m}^{3} \mathrm{FYM} /$ fad came in the second rank for seed yield/fad after solid culture of faba bean that fertilized with $20 \mathrm{~kg} \mathrm{~N} /$ fad. These results could be attributed to a decrease in mineral $\mathrm{N}$ fertilizer rate from 90 to 70 $\mathrm{kg} \mathrm{N} /$ fad enhanced the efficiency of faba bean to fix more atmospheric $\mathrm{N}_{2}$ and solubilize $\mathrm{P}$ as a result of the production of organic acids and enzymes [53]. It is known that the interaction between soil type, plant species and rhizosphere localization of bacterial community affected bacterial community composition [54]. Moreover, the contents of FYM (Table 2) may be integrated positively with rhizobia of faba bean plants in their rhizosphere. Adequate moisture availability in soil increased various physiological processes, better of nutrients uptake, higher rates of photosynthesis which might reflected on more number and area of leaves and higher yields [55]. Thus, it is likely that the intercropping faba bean with sugar beet that fertilized with $70 \mathrm{~kg} \mathrm{~N}+30 \mathrm{~m}^{3} \mathrm{FYM} /$ fad sustained growth of new tillers development during pod-setting and seed filling compared with the other treatments as a result of increasing soil $\mathrm{N}$ availability. These results show that there was some degree of resource complimentarily between the two species by decreasing mineral $\mathrm{N}$ fertilizer rate from 90 to $70 \mathrm{~kg} \mathrm{~N} /$ fad.

\subsection{Competitive Relationships}

\subsubsection{Land Equivalent Ratio (LER)}

Data in Figure 1 show that relative yield (RY) of sugar beet contributed positively 

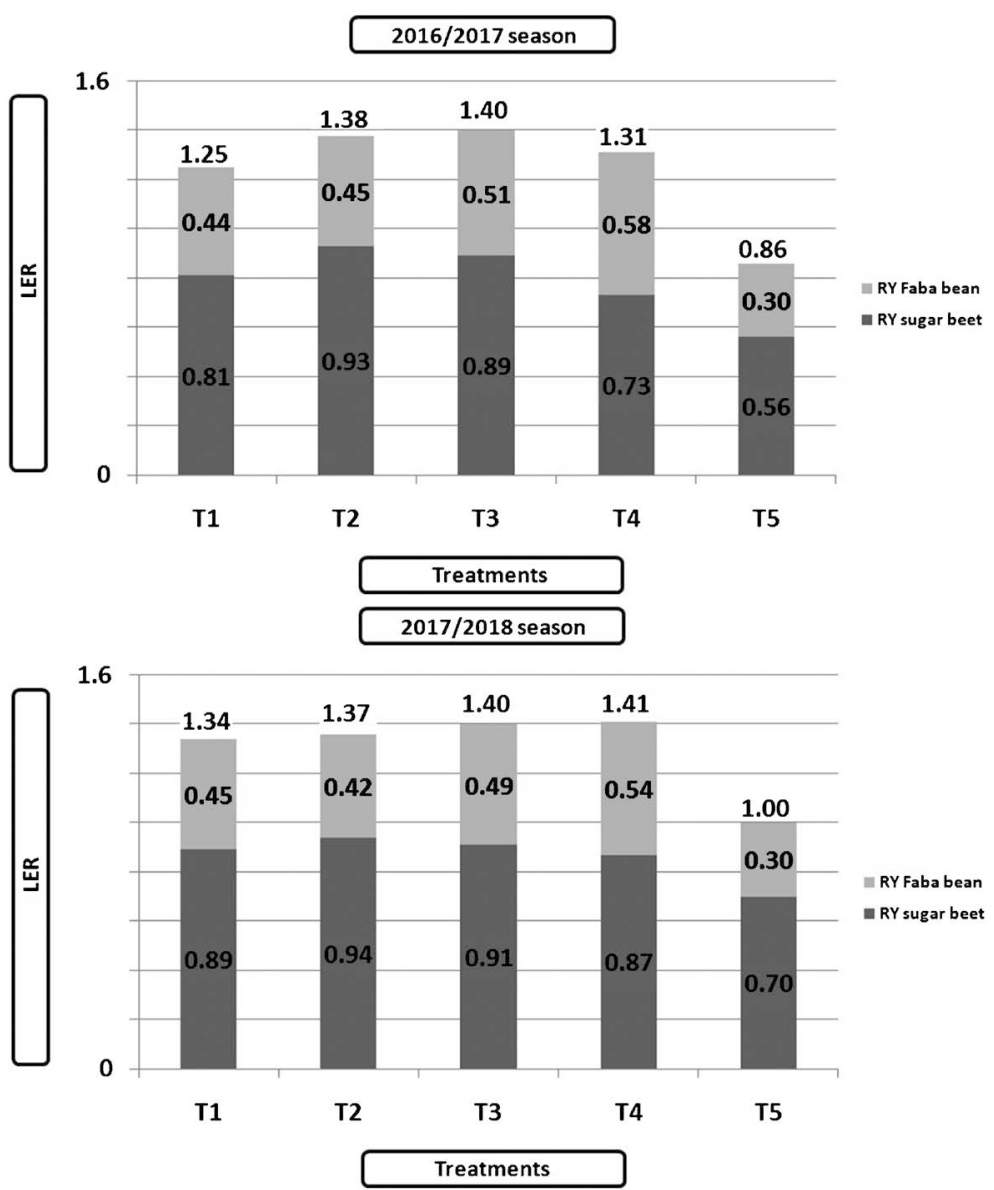

Figure 1. Response of intercropping faba bean with sugar beet to bio-organic additives and mineral N fertilizer rates on LER in 2016/2017 and 2017/2018 seasons.

in LER more than RY of faba bean in both seasons. LER values were ranged between 0.86 and 1.40 in the first season and 1.00 and 1.41 in the second season. In general, the highest LER was achieved when faba bean intercropped with sugar beet and fertilized by $\mathrm{T}_{3}\left(80 \mathrm{~kg} \mathrm{~N}+30 \mathrm{~m}^{3} \mathrm{FYM} / \mathrm{fad}\right)$. On the other hand, the lowest LER ( 0.86 and 1.00 in the first and second seasons, respectively) was achieved by the application of $\mathrm{T}_{5}\left(400 \mathrm{~g}\right.$ of Cerealine $\left.+30 \mathrm{~m}^{3} \mathrm{FYM} / \mathrm{fad}\right)$ for intercropping faba bean with sugar beet.

It is likely that that $\mathrm{T}_{5}\left(400 \mathrm{~g}\right.$ of Cerealine $+30 \mathrm{~m}^{3} \mathrm{FYM} /$ fad) increased intra and inter-specific competition between the same and different species, respectively for climatic and edaphic environmental conditions compared with the other treatments. These results reveal that application of $80 \mathrm{~kg} \mathrm{~N}+30 \mathrm{~m}^{3}$ FYM/fad for intercropping faba bean with sugar beet caused a yield advantage because of the component crops were differed in their utilization of growth resources. Similar results were obtained by El-Shamy et al. [27] and Hamadany and El-Aassar [56].

\subsubsection{Land Equivalent Coefficient (LEC)}

LEC is a measure of interaction concerned with the strength of relationship. LEC 
is used for a two-crop mixture the minimum expected productivity coefficient (PC) is 25 percent, that is, a yield advantage is obtained if LEC value was exceeded 0.25. Data in Figure 2 show that relative yield (RY) of sugar beet contributed positively in LEC more than RY of faba bean in both seasons. LEC values were ranged between 0.30 and 0.45 in the first season and 0.30 and 0.46 in the second season. In general, the highest LEC was achieved when faba bean intercropped with sugar beet and fertilized by $\mathrm{T}_{3}\left(80 \mathrm{~kg} \mathrm{~N}+30 \mathrm{~m}^{3} \mathrm{FYM} / \mathrm{fad}\right)$. On the other hand, the lowest LEC ( 0.30 in both seasons) was achieved by the application of $\mathrm{T}_{5}$ (400 $\mathrm{g}$ of Cerealine $+30 \mathrm{~m}^{3} \mathrm{FYM} /$ fad) for intercropping faba bean with sugar beet.

It is likely that that $\mathrm{T}_{5}\left(400 \mathrm{~g}\right.$ of Cerealine $\left.+30 \mathrm{~m}^{3} \mathrm{FYM} / \mathrm{fad}\right)$ increased intra and inter-specific competition between the same and different species, respectively for climatic and edaphic environmental conditions compared with the other treatments. Application of $\mathrm{T}_{3}\left(80 \mathrm{~kg} \mathrm{~N}+30 \mathrm{~m}^{3} \mathrm{FYM} / \mathrm{fad}\right)$ for intercropping faba bean with sugar beet caused a yield advantage because of the component crops were differed in their utilization of growth resources.

\subsubsection{Relative Crowding Coefficient (RCC)}

Data in Figure 3 indicate that RCC was higher than the unit advantage in all
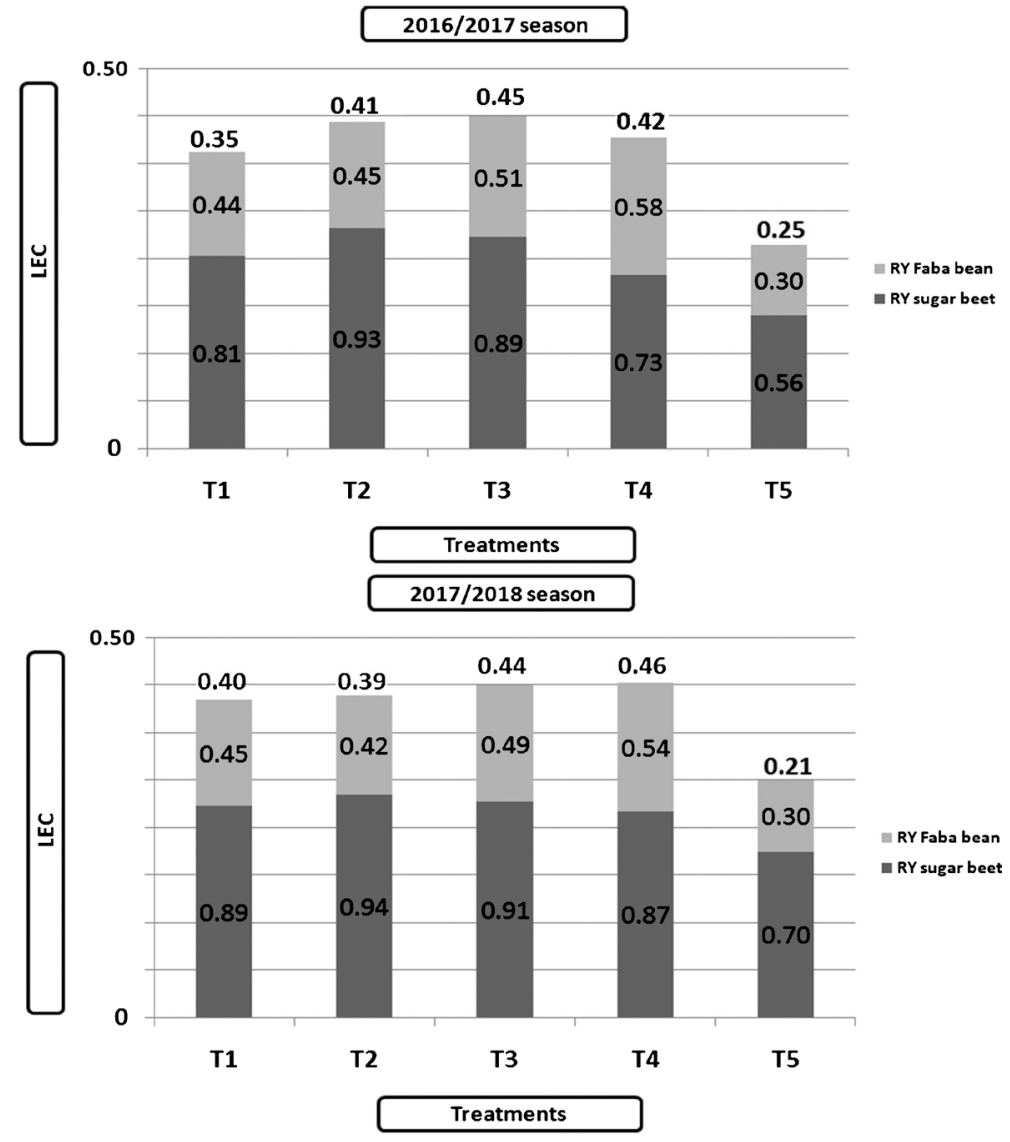

Figure 2. Response of intercropping faba bean with sugar beet to bio-organic additives and mineral $\mathrm{N}$ fertilizer rates on LEC in 2016/2017 and 2017/2018 seasons. 


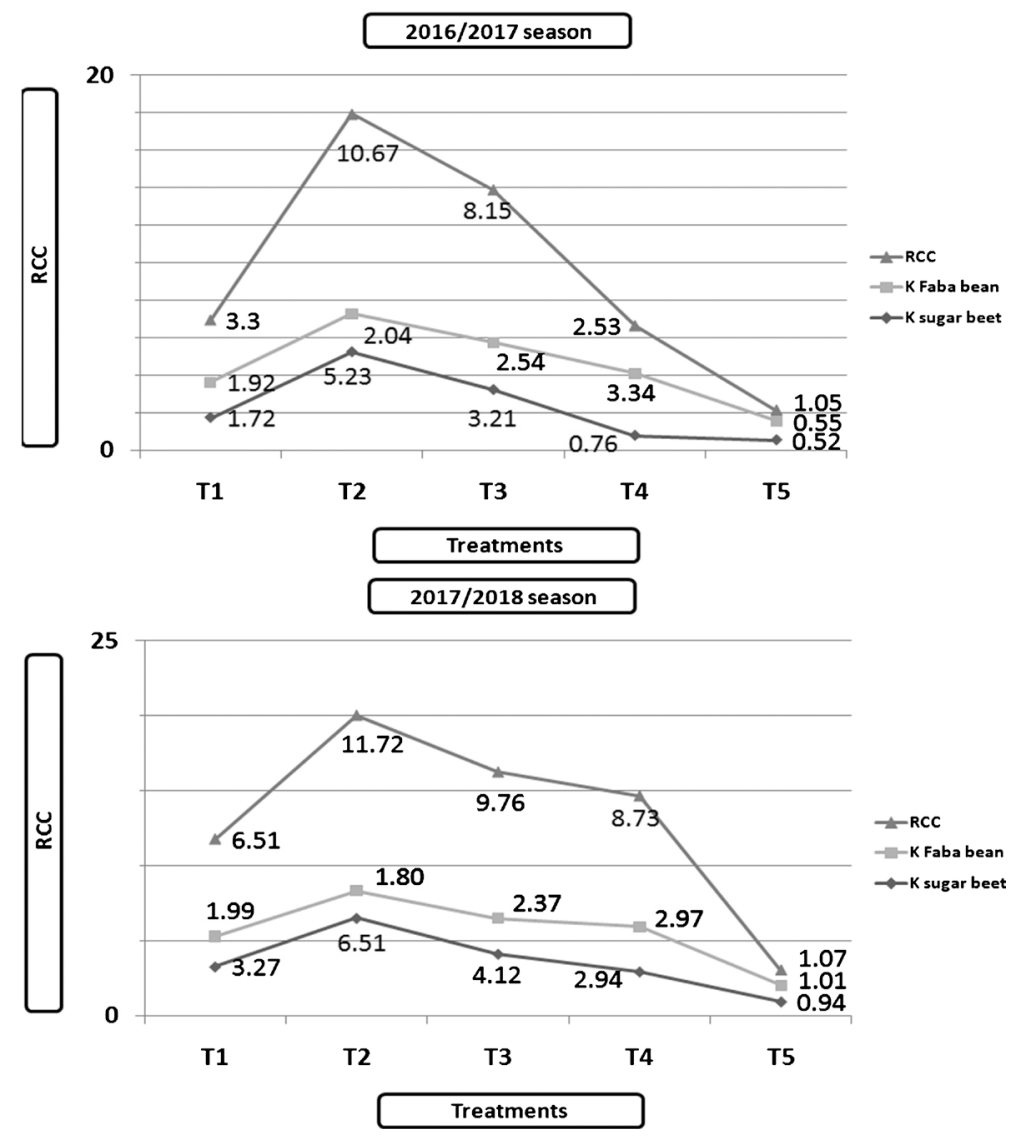

Figure 3. Response of intercropping faba bean with sugar beet to bio-organic additives and mineral N fertilizer rates on RCC in 2016/2017 and 2017/2018 seasons.

treatments in both seasons. The best results were obtained by application of $\mathrm{T}_{2}$ $\left(90 \mathrm{~kg} \mathrm{~N}+30 \mathrm{~m}^{3} \mathrm{FYM} / \mathrm{fad}\right)$ for intercropping faba bean with sugar beet (10.68 and 11.75 in the first and second seasons, respectively) followed by $\mathrm{T}_{3}(80 \mathrm{~kg} \mathrm{~N}+$ $30 \mathrm{~m}^{3} \mathrm{FYM} / \mathrm{fad}$ ). Meanwhile, the reverse was true for $\mathrm{T}_{5}(400 \mathrm{~g}$ of Cerealine +30 $\mathrm{m}^{3} \mathrm{FYM} / \mathrm{fad}$ ) in both seasons, where RCC value was 0.55 in the first season and 1.01 in the second season. These results could be due to the increase in mineral $\mathrm{N}$ fertilizer rate from 70 to $90 \mathrm{~kg} \mathrm{~N} / \mathrm{fad}$ integrated positively with FYM to enhance growth and yield components traits for both species that reflected positively on their yields. Similar results are in accordance with El-Din [10].

\subsubsection{Aggressivity (Agg)}

Results in Figure 4 show that faba bean was the dominant intercropped components and sugar beet was dominated in all treatments in both seasons. These results may be due to there was higher intra-specific competition between plants of sugar beet than faba bean plants for available environmental resources. The present results reveal clearly that plants of faba bean had higher competitive abilities for basic growth resources than sugar beet plants. Faba bean was more aggressive than that of sugar beet. Accordingly, decreasing mineral $\mathrm{N}$ fertilizer rate from 90 to $70 \mathrm{~kg} \mathrm{~N} /$ fad generated high competition for assimilate distribution 


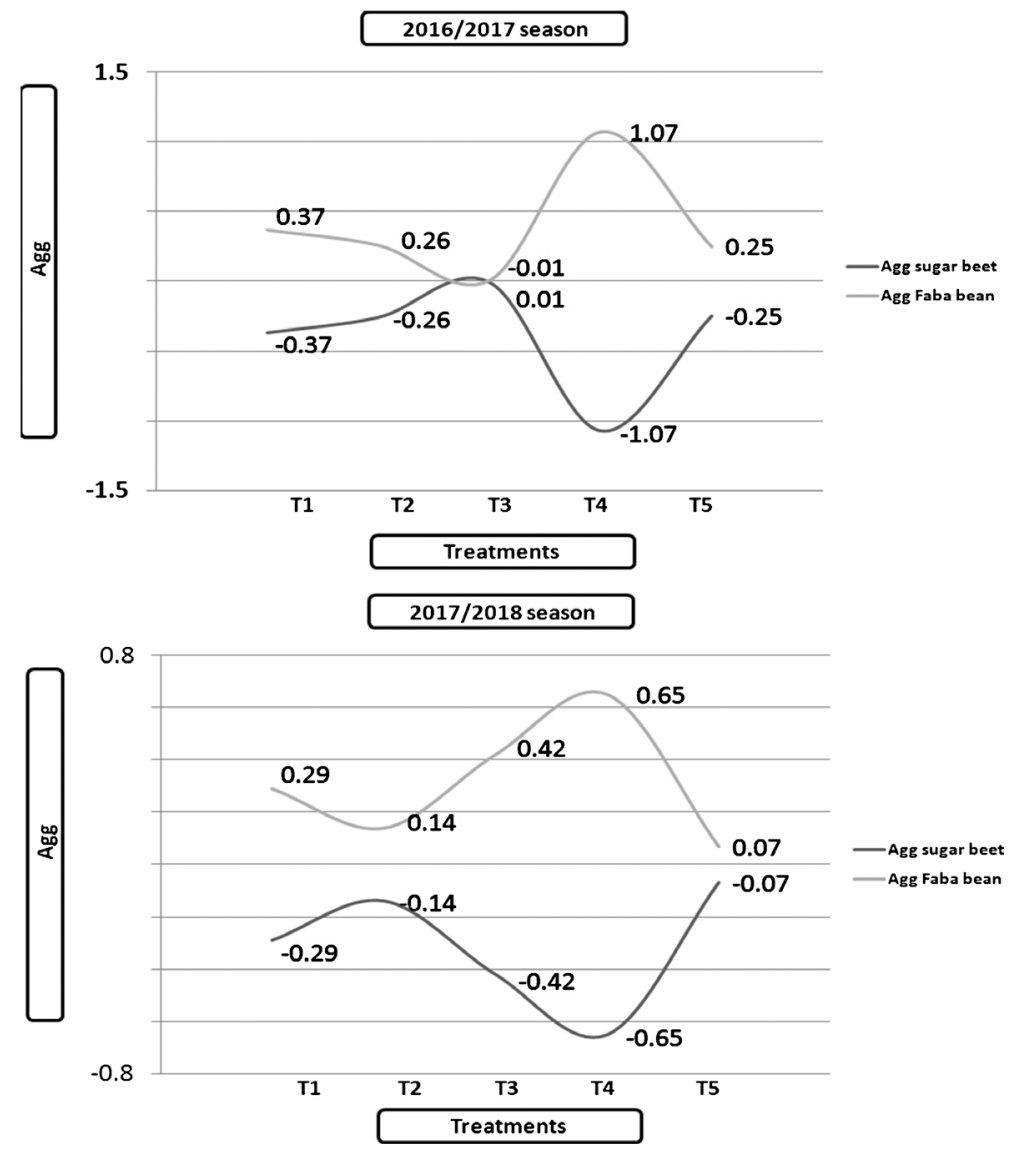

Figure 4. Response of intercropping faba bean with sugar beet to bio-organic additives and mineral N fertilizer rates on Agg in 2016/2017 and 2017/2018 seasons.

between organs of sugar beet plant, and then affected negatively top, root and sugar yield/fad.

\subsection{Intercropping Economic Advantage}

\subsubsection{Total Income}

Total income of intercropped faba bean with sugar beet compared with solid culture of sugar beet are shown in Table 5. Total income values were ranged between 13,561 L.E./fad and 21,907 L.E./fad in the first season, and 16,544 L.E./fad and 22,946 L.E./fad in the second season.

Intercropping faba bean with sugar beet with application of $\mathrm{T}_{2}(90 \mathrm{~kg} \mathrm{~N}+30$ $\left.\mathrm{m}^{3} \mathrm{FYM} / \mathrm{fad}\right)$ and $\mathrm{T}_{3}\left(80 \mathrm{~kg} \mathrm{~N}+30 \mathrm{~m}^{3} \mathrm{FYM} /\right.$ fad) increased total income by 23.31 and $22.91 \%$, respectively, compared with solid culture of sugar beet in the first season. In the second season, intercropping faba bean with sugar beet with application of $\mathrm{T}_{4}\left(70 \mathrm{~kg} \mathrm{~N}+30 \mathrm{~m}^{3} \mathrm{FYM} / \mathrm{fad}\right)$ and $\mathrm{T}_{3}\left(80 \mathrm{~kg} \mathrm{~N}+30 \mathrm{~m}^{3} \mathrm{FYM} / \mathrm{fad}\right)$ increased total income by 27.13 and $26.28 \%$, respectively, compared with solid culture of sugar beet.

\subsubsection{MAI}

The economic performance of the intercropping was evaluated to determine if 
Table 5. Response of intercropping faba bean with sugar beet to bio-organic additives and mineral $\mathrm{N}$ fertilizer rates on intercropping economic advantage in 2016/2017 and 2017/2018 seasons.

\begin{tabular}{ccccc}
\hline \multirow{2}{*}{ Treatments } & \multicolumn{2}{c}{ Total income (L.E./fad) } & \multicolumn{2}{c}{ MAI } \\
\cline { 2 - 5 } & $2016 / 2017$ & $2017 / 2018$ & $2016 / 2017$ & $2017 / 2018$ \\
\hline $\mathrm{T}_{1}$ & 19,691 & 21,844 & 3938.20 & 5542.50 \\
$\mathrm{~T}_{2}$ & 21,907 & 22,476 & 6032.36 & 6070.16 \\
$\mathrm{~T}_{3}$ & 21,835 & 22,792 & 6238.57 & 6512.00 \\
$\mathrm{~T}_{4}$ & 19,867 & 22,946 & 4701.35 & 6672.24 \\
$\mathrm{~T}_{5}$ & 13,561 & 16,544 & -- & -- \\
$\mathrm{T}_{6}$ & 17,765 & 18,048 & -- & -- \\
\hline
\end{tabular}

faba bean and sugar beet combined yields are high enough for the farmers to adopt this system. In the first season, intercropping faba bean with sugar beet with application of $\mathrm{T}_{3}\left(80 \mathrm{~kg} \mathrm{~N}+30 \mathrm{~m}^{3} \mathrm{FYM} / \mathrm{fad}\right)$ were higher in MAI than the other treatments (Table 5). Meanwhile, intercropping faba bean with sugar beet with application of $\mathrm{T}_{4}\left(70 \mathrm{~kg} \mathrm{~N}+30 \mathrm{~m}^{3} \mathrm{FYM} / \mathrm{fad}\right)$ or $\mathrm{T}_{3}\left(80 \mathrm{~kg} \mathrm{~N}+30 \mathrm{~m}^{3} \mathrm{FYM}\right)$ were higher in MAI than the other treatments in the second one. There were gradual and consistent increases in MAI values with decreasing mineral $\mathrm{N}$ fertilizer rate from 90 to $80 \mathrm{~kg} \mathrm{~N} /$ fad under intercropping conditions. These results reveal that intercropping faba bean with sugar beet with application of $80 \mathrm{~kg} \mathrm{~N}+$ $30 \mathrm{~m}^{3} \mathrm{FYM} /$ fad gave high MAI and could be recommended. Application of $\mathrm{T}_{5}$ (400 g of Cerealine $+30 \mathrm{~m}^{3} \mathrm{FYM} / \mathrm{fad}$ ) for intercropping faba bean with sugar beet resulted in a major economic loss as evidence of MAI demonstrated this economic failure with application of Cerialine as a supplement to mineral nitrogen deficiency. Generally, these results indicate that growing faba bean with sugar beet that fertilized by $80 \mathrm{~kg} \mathrm{~N}+30 \mathrm{~m}^{3} \mathrm{FYM} /$ fad is more profitable to farmers than solid culture of sugar beet that received $90 \mathrm{~kg} \mathrm{~N} / \mathrm{fad}$. Similar results were obtained by Soliman et al. [57] and El-Shamy et al. [27].

\section{Conclusion}

According to our results, it can be concluded that the combination of mineral $\mathrm{N}$ fertilizer ( $80 \mathrm{~kg} \mathrm{~N} / \mathrm{fad})$ with FYM ( $\left.30 \mathrm{~m}^{3} / \mathrm{fad}\right)$ has a better impact on the soil nutrient availability, yields of the intercrops (faba bean and sugar beet), competitive relationships and yield advantage than growing sugar beet alone that received the recommended mineral $\mathrm{N}$ fertilizer rate.

\section{Conflicts of Interest}

The authors declare no conflicts of interest regarding the publication of this paper.

\section{References}

[1] Zadeh, M. and Mousavi, S.F. (1996) Surface Irrigation (Theory and Practice). Pub- 
lications Dictionary Tehran, Tehran.

[2] UNESCO (2006) Water, a Shared Responsibility, Rep. 2, World Water Assess. Programme, Berghann, New York.

[3] Ahmed, S.E., Abou-Salama, A.M., El-Naggar, G.R. and Abdel-Motagally, F.M.F. (2009) Studies on Legume-Black Cumin Intercropping. Egyptian Journal of Applied Sciences, 24, 553-563.

[4] Yao, R.J., Yang, J.S., Chen, X.B., Yu, S.P. and Li, X.M. (2009) Fuzzy Synthetic Evaluation of Soil Quality in Coastal Reclamation Region of North Jiangsu Province. Scientia Agricultura Sinica, 42, 2019-2027. (In Chinese)

[5] Kumar, B., Tiwana, U.S., Singh, A. and Ram, H. (2014) Productivity and Quality of Intercropped Maize (Zea mays L.) + Cowpea [Vigna unguiculata (L.) Walp.] Fodder as Influenced by Nitrogen and Phosphorus Levels. Range Management and Agroforestry, 35, 263-267.

[6] Ouda, S.M.M. (2001) Response of Sugar Beet to N and K Fertilizers Levels under Sandy Soil Conditions. Zagazig Journal of Agricultural Research, 28, 275-297.

[7] Mohammed, W.Kh., El-Metwally, A. and Saleh, S.A. (2005) Intercropping Faba Bean at Different Plant Densities with Sugar Beet. Egyptian Journal of Agricultural Research, 83, 649-663.

[8] El-Ghobashi, Y.E. (2007) Studies on Intercropping Some Winter Crops on Sugar Beet Crop in Newly Reclaimed Soils. M.Sc. Thesis, Fac. Agric., Al-Azhar Univ., Cairo.

[9] Abdel-Galil, A.M., El-Ghobashi, Y.E. and Lamlom, M.M. (2014) Sugar Beet Productivity and Profitability as Affected by Three Cropping Systems and Mineral Nitrogen Fertilizer Rates. The 8th International Conference on Technology and Sustainable Development in the Third Millennium, Alexandria, 22-24 November 2014, 161-188.

[10] El-Dein, A.A.M.Z. (2015) Effect of Intercropping Some Winter Crops with Sugar Beet under Different Nitrogen Fertilizer on Yield and Its Components. Global Journal of Agriculture and Food Safety Sciences, 2, 303-318.

[11] Sharma, A.R. and Mittra, B.N. (1991) Effect of Different Rates of Application of Organic and Nitrogen Fertilizers in a Rice-Based Cropping System. The Journal of Agricultural Science, 117, 313-318. https://doi.org/10.1017/S0021859600067046

[12] El-Shafai, A.M.A. (2000) Effect of Nitrogen and Potassium on Yield and Quality of Sugar Beet in Sohag. Egyptian Journal of Agricultural Research, 78, 759-767.

[13] Dao, T.H. and Cavigellib, M.A. (2003) Mineralizable Carbon, Nitrogen, and Water-Extractable Phosphorus Release from Stockpiled and Composted Manure and Manure-Amended Soils. Agronomy Journal, 95, 405-413. https://doi.org/10.2134/agronj2003.0405

[14] Celik, I., Ortas, I. and Kilic, S. (2004) Effects of Compost, Mycorrhiza, Manure and Fertilizer on Some Physical Properties of a Chromoxerert Soil. Soil \& Tillage Research, 78, 59-67. https://doi.org/10.1016/j.still.2004.02.012

[15] Hassanien, H.G., Abd El-mola, S.E., Amin, A.A. and El-Sayed, H.K. (2017) Effect of Farmyard Manure and Rate of Phosphatic Fertilizer on Phosphorus Availability and Yield of Corn. Assiut Journal of Agricultural Sciences, 48, 347-355. https://doi.org/10.21608/ajas.2016.3864

[16] Zalat, S.S. and Nemeat Alla, E.A.E. (2001) Yield and Quality of Sugar Beet as Affected by Inorganic and Nitrogen Fertilizer. Minoufiya Journal of Agricultural Research, 26, 1187-1193. 
[17] Javaheri, M.A., Rashidi, N., Baghizadeh, A. and Gohari, J. (2005) Influence of Organic Farm Yard Manure, Potassium and Boron on Quantity and Quality of Sugar Beet in Bardsir Region. Sugar Beet Journal (Iran), 21, 43-56.

[18] Taleghani, D.F., Hemayati, S.S., Noshad, H., Dehghanshoar, M., Tohidloo, G. and Hamdi, F. (2006) Effects of Different Manuring Levels on Some Quantity and Quality Factors of Sugar Beet in Wheat Sugar Beet Rotation. Sugar Beet Journal (Iran), 22, 67-78.

[19] Maid, F.X. and Fischbeck, G. (2008) Effect of Long-Term Application of Farmyard Manure on Growth and Quality of Sugar Beet. Journal of Agronomy and Crop Science, 162, 248-255. https://doi.org/10.1111/j.1439-037X.1989.tb00714.x

[20] El-Agrodi, M.W.M., El-Zehery, T.M. and Issa, H.L. (2011) Effect of Chicken Manure and Gypsum on Sugar Beet (Betavulgaris, var. saccharifora, L.) under Saline Condition. Journal of Soil Sciences and Agricultural Engineering, 2, 701-716. https://doi.org/10.21608/jssae.2011.55652

[21] Zhang, F. and Li, L. (2003) Using Competitive and Facilitative Interactions in Intercropping Systems Enhances Crop Productivity and Nutrient-Use Efficiency. Plant and Soil, 248, 305-312. https://doi.org/10.1023/A:1022352229863

[22] Abdel-Wahab, A.F. and Said, M.S. (2004) Response of Faba Bean to Bio and Organic Fertilization under Calcareous Soil Conditions. Egyptian Journal of Applied Sciences, 19, 305-320.

[23] Mahmoud, A.R., Hafez, M.M. and Abd-Elal, F.S. (2004) Comparative Study for Using Organic Manure as Individual and/or Mixing It with Chemical Fertilizer and Their Effects on the Productivity of Vicia faba Plants. The Journal of Agricultural Science, 29, 1345-1354.

[24] Mohamed, H.A. and Gomaa, A.M. (2005) Faba Bean Growth and Green Yield and Its Quality as Influenced by the Application of Bio-Organic Farming System. Journal of Applied Sciences Research, 1, 380-385.

[25] Moore, A., Stark, J., Brown, B. and Hopkins, B. (2009) Sugar Beets. Southern Idaho Fertilizer Guide. University of Idaho Extension, Moscow.

[26] Mahmoud, E.A., Ramadan, B.S.H., El-Geddawy, I.H. and Korany, S.F. (2014) Effect of Mineral and Biofertilization on Productivity of Sugar Beet. Journal of Plant Production, 5, 699-710. https://doi.org/10.21608/jpp.2014.53887

[27] El-Shamy, M.A., Hamadany, M.K. and Abdel-Dayem, I.M. (2016) Effect of Faba Bean Sowing Distance and Some Combinations of Mineral Nitrogen Levels with Bio Fertilizers on Sugar Beet and Faba Bean Productivity under Intercropping System Egyptian Journal of Agronomy, 38, 489-507.

https://doi.org/10.21608/agro.2017.291.1030

[28] Chapman, H.D. and Pratt, P.E. (1961) Methods of Analysis for Soils, Plants and Waters. Division of Agricultural Sciences, University of California, San Diego.

[29] A.O.A.C. (1990) Official Methods of Analysis of the Association of Official Agricultural Chemists. 15th Edition, Washington DC.

[30] Carruthers, A. and Oldfield, J.F.T. (1960) Methods for the Assessment of Sugar Beet Quality. International Sugar Journal, 63, 72-74.

[31] Andrews, D.J. and Kassam, A.H. (1976) The Importance of Multiple Cropping in Increasing World Food Supplies. In: Papendick, R.I., Sanchez, A. and Triplett, G.B., Eds., Multiple Cropping, Spec. Publ. No. 27, Am. Soc. of Agron., Madison, 1-10. https://doi.org/10.2134/asaspecpub27.c1 
[32] Adetiloye, P.O., Ezedinma, F.O.C. and Okigbo, B.N. (1983) A Land Equivalent Coefficient Concept for the Evaluation of Competitive and Productive Interactions on Simple Complex Mixtures. Ecological Modelling, 19, 27-39. https://doi.org/10.1016/0304-3800(83)90068-6

[33] Banik, P., Midya, A., Sarkar, B.K. and Ghose, S.S. (2006) Wheat and Chickpea Intercropping Systems in an Additive Series Experiment: Advantages and Weed Smothering. European Journal of Agronomy, 24, 325-332. https://doi.org/10.1016/j.eja.2005.10.010

[34] Mc-Gilchrist, C.A. (1965) Analysis of Competition on Experiments. Biometrics, 21, 975-985. https://doi.org/10.2307/2528258

[35] Willey, R.W. (1979) Intercropping Its Importance and Research Needs. Part I: Competition and Yield Advantages. Field Crops Abstract, 32, 1-10.

[36] Bulletin of Statistical Cost Production and Net Return (2017) Winter Field Crops and Vegetables and Fruit. Agriculture Statistics and Economic Sector, Ministry of Egyptian Agriculture and Land Reclamation, Part (1), February 2017, Egypt.

[37] Gomez, K.N. and Gomez, A.A. (1984) Statistical Procedures for Agric. Research. 2nd Edition, J. Wiley and Sons, Inc., New York, 68 p.

[38] Hagedorn, F., Spinnler, D. and Siegwolf, R. (2003) Increased N Deposition Retards Mineralization of Old Soil Organic Matter. Soil Biology and Biochemistry, 35, 1683-1692. https://doi.org/10.1016/j.soilbio.2003.08.015

[39] Johnston, A.E., Poulton, P.R. and Coleman, K. (2009) Soil Organic Matter: Its Importance in Sustainable Agriculture and Carbon Dioxide Fluxes. Advances in Agronomy, 101, 1-57. https://doi.org/10.1016/S0065-2113(08)00801-8

[40] Paré, M.C. and Bedard-Haughn, A. (2013) Soil Organic Matter Quality Influences Mineralization and GHG Emissions in Cryosols: A Field-Based Study of Sub-To High Arctic. Global Change Biology, 19, 1126-1140. https://doi.org/10.1111/gcb.12125

[41] El-Shahawy, M.I., Abd El-Wahab, S.A., Sobh, M.M. and Nemeatalla, E.A.E. (2002) Productivity and NPK Uptake of Sugar Beet as Influenced by N, B and Mn Fertilization. The Journal of Agricultural Science, 27, 1955-1964.

[42] Ramadan, B.S.H., Hassan, H.R. and Abdou, F.A. (2003) Effect of Mineral and Biofertilizers on Photosynthetic Pigments, Root Quality, Yield Components and Anatomical Structure of Sugar Beet (Beta vulgaris L.) Plants Grown under Reclaimed Soils. The Journal of Agricultural Science, 28, 5139-5160.

[43] Abd-El-Kader, E.M.A. (2011) Effect of Nitrogen Fertilizer Rates and Some Growth Regulators Treatments on Sugar Beet. Agricultural Science, 2, 1693-1702.

[44] Gibson, L., Jeremy, S. and Stephen, B. (2006) Intercropping Winter Cereal Grains and Red Clover. Univ. Extension, Iowa State University, Ames. http://file:///C:/Users/hp/Downloads/PM2025\%20(1).pdf

[45] Zhang, J.B., Yang, J.S., Yao, R.J., Yu, S.P., Li, F.R. and Hou, X.J. (2014) The Effects of Farmyard Manure and Mulch on Soil Physical Properties in a Reclaimed Coastal Tidal Flat Salt-Affected Soil. Journal of Integrative Agriculture, 13, 1782-1790. https://doi.org/10.1016/S2095-3119(13)60530-4

[46] Timmusk, S. and Wagner, E.G.H. (1999) The Plant-Growth Promoting Rhizobacterium Paenibacillus polymyxa Induces Changes in Arabidopsis thaliana Gene Expression: A Possible Connection between Biotic and Abiotic Stress Responses. Molecular Plant-Microbe Interactions, 12, 951-959.

https://doi.org/10.1094/MPMI.1999.12.11.951 
[47] Aly, M.H.A., Zeinab, R.M. and Osman, A.M.H. (2009) Effect of Seed Inoculation and Foliar Application with Azospirillum brasiliense and/or Bacillus megatherium on Productivity and Quality of Sugar Beet. Egyptian Journal of Applied Sciences, 24, 56-70.

[48] El-Fadaly, H.A., El-Geddawy, I.H., El-Hawary, F.I. and Ebrahim, A. (2013) Enumeration of Rhizobacteria Count and Growth Criteria of Sugar Beet Plant as Affected by Biofertilization. Egyptian Journal of Agricultural Research, 91, 657-673.

[49] Afify, A.H., Hammouda, F.M., Basyouny, A.M. and Hauka, F.A. (1994) Effect of Bacterization and Mineral Fertilization on the Main Characters and Major Insect Infestations of Sugar Beet Plants. The Journal of Agricultural Science, 19, 201-208.

[50] Buraczynska, D., Ceglarek, F. and Paza, A. (2001) The Influence of Different Organic Fertilization on Sugar Beet Crop in the Middle Eastern Part of Poland Part. Technological Quality of Sugar Beet. Roczniki Nauk. Rolniczych Seria A, produkcja Roslinna, 115, 55-65.

[51] Ali, M.H.A. (2003) Microbiological Chemical Studies on the Rhizosphere of Sugar Beet Plants. PhD Thesis, Fac. Agric., Al Azhar Univ., Cairo.

[52] Omar, M.I. (2007) Effect of Potassium and Organic Fertilizer on the Productivity of Some Sugar Beet Varieties under Saline Conditions. PhD Thesis, Fac. Agric., Alexandria Univ., Alexandria.

[53] Kumar, V. and Narula, N. (1999) Solubilization of Inorganic Phosphates and Growth Emergance of Wheat as Affected by Azotobacter chroococcum. Biology and Fertility of Soils, 28, 301-305. https://doi.org/10.1007/s003740050497

[54] Marschner, P., Yang, C.H., Lieberei, R. and Crowley, D.E. (2001) Soil and Plant Specific Effects on Bacterial Community Composition in the Rhizosphere. Soil Biology and Biochemistry, 33, 1437-1445. https://doi.org/10.1016/S0038-0717(01)00052-9

[55] El-Gindy, A.M., Abdel-Aziz, A.A., El-Sabar, E.A. and Abdelghany, A.M. (2003) Engineering and Biological Properties of Faba Bean Seeds under Different Irrigation Systems. The Journal of Agricultural Science, 28, 4325-4337.

[56] Hamadany, M.Kh. and El-Aassar, M.R. (2017) Effect of Intercropping Faba Bean Varieties with Sugar Beet Plants on Piercing Sucking Insect Pests and Associated Natural Enemies under Ridge Space and Seedling Rates in Relation to Crop Yield. Egyptian Academic Journal of Biological Sciences, 10, 57-77. https://doi.org/10.21608/eajb.2017.12125

[57] Soliman, E.M., El-Hawary, M.A., Abdel-Aziz, M., Mazen, O.A.O. and Mohamed, S.A. (2013) Effect of Irrigation Water Quantity, Sources and Rates of Nitrogen on Growth and Quality of Sugar Beet. Journal of Plant Production, 4, 537-550.

https://doi.org/10.21608/jpp.2013.72407 